\title{
Nigeria's economic growth and The Sisyphus Odyssey: a theoretical retrospect
}

\section{Lasbrey Anochiwa*; Tobechi Agbanike; Denis Nfor Yuni; Basil Chukwu}

\author{
Department Of Economics and Development Studies, Alex Ekwueme Federal \\ University Ndufu- Alike, Nigeria \\ *To whom correspondence should be addressed. Email:lanochiwa@yahoo.com
}

\begin{abstract}
We posit in the paper that getting out of Dutch disease or resource curse in Nigeria will be a mirage if the more potent disease of institutional decay, ethnicity and religious bigotry are not settled. Those who have opportunity to advice the country has over the years wrongly fixated on the rise or fall of GDP and foreign investment flows as attention is now centered on extraction industry. We recognize institutional factors as major determinants of growth in Nigeria. From our analysis it is observed that Nigeria has indeed fallen into the trap of Dutch disease and resource curse phenomenon. We also observe that Nigeria is ethnic bias and highly religious in virtually everything. And every policy of the government (economic, social or political) is weighed on the scale of religion or ethnic benefit. It is equally sad to note the quantum of resources engaged to curtail ethnic clashes as well deaths and IDPs. As Nigeria is governed by ethnic sentiments and religious bigotry, it increases the tendency for corruption and its attendant negative economic consequences. These constitute serious impediments and make the task of growth Sisyphean.
\end{abstract}

Keywords: Dutch disease, Economic growth, Resources curse, Sisyphus

JEL Classification: 040, 043, 044

\section{INTRODUCTION}

Nigeria, a multi-ethnic country of about 180 million people is in dire need to grow. Feeding the teaming population and giving hope of sustenance to this people largely depends on its growth trajectory and a clear understanding of the country's historical antecedents. We know economic growth may not necessarily account for development, yet the reality is that the material conditions of a people may not change for better in the absence of economic growth (Anochiwa and Maduka, 2014). The world is fast embracing institutional factors and gradually 'delinking' from the orthodox theories of (Solow, 1956; Chenery, Hollis and Strout, 1966; Harrod, 1939; Domar, 1946) in seeking for explanations for the backwardness of the less developed countries (LDCs). The idea that LDCs might suffer negative economic effects from over dependence on modernization theories has a long pedigree.

Even as attention is shifting towards the new growth models and its incorporation of human capital (Romer, 1993, Barro et al 1995), it is still not enough to account for the growth disparity. Models of growth must contextually, be situated. No growth model can operate in isolation of the environment. There is therefore a compelling need, 
perhaps due to its peculiar nature to go back to a political economy (historical science) approach in ascertaining determinants of growth in some LDCs, especially Nigeria (Jevons, 1879; Ordeshook, 1990).

That Nigeria has abundant oil resources is no longer debatable, as she ranks among the highest oil producing countries in Africa. Again, that oil is the mainstay of the economy of Nigeria is also a reality, a reality that gained prominence since Nigeria's independence in 1960. It is this prominence and dependence on oil over and above other sources of revenue and the necessary fall-outs, that made her gain a place in the 'Dutch disease syndrome'. Curbing the disease as it were to make Nigeria grow, has excavated similar 'diseases' like 'resource curse' and the deep rooted ethno-religious divide, such that it has become more complicated and intractable in solving. Regrettably, Nigeria is among the poorest economies in the world even when she is ranked the largest economy in Africa, which is a paradox of economic growth hypothesis (Anochiwa and Maduka, 2014). As the country forges ahead 57 years after independence, with up-swing and down-swing phenomenon in the economic front, never getting a footing to stand, one is being reminded of the 'Sisyphus Odyssey'.

While we appall the part of dishonor Nigeria has played in neglecting to learn lessons from mistakes of other mineral dependent countries, it will be equally revealing to look inwards to see other 'potent diseases' that has reinforced the crippling of the economy of Nigeria, than to constantly worship at the 'altar of orthodox theories' and latch on generalizations of Dutch disease. To this, the phenomenon 'Dutch disease', though pervasive and prevalent in Nigeria, may be too tangential when compared to other 'internal diseases' that have kept Nigeria low.

It is these crippling and contending factors that we refer to as 'the sons of Sisyphus at work'. In this paper, the sons of Sisyphus are not particularly Dutch disease but include, institutional factors, resource curse, ethnic and religious conflicts, which together act to hinder economic growth (Acemoglu et al 2005b). We shall be looking at the role these factors have played in frustrating the development stride of Nigeria. As a way of methodology, we shall explain the Sisyphus phenomenon, as we consider the role of Dutch disease to Nigeria's economic woes, resource curse and economic growth, economic growth and ethnicity, the role of religion to economic growth and finally economic growth in Nigeria beyond rhetoric's.

\section{NIGERIA'S ECONOMIC GROWTH AS SISYPHUS ODYSSEY}

In Greek mythology Sisyphus was the son of a King named Aeolus of Thessaly and Enarete. He was the founder and first king of Ephyra (supposedly the original name of Corinth). King Sisyphus promoted business and commerce but was greedy and double-faced. He frustrated, killed and violate people's rights, even strangers. He took pleasure in the sufferings and killings because fear and docile polity. The gods finally threatened to make life so miserable for Sisyphus that he would wish he were dead. He was punished for his unashamed craftiness and deceitfulness by being forced to endlessly roll an immense huge boulder up a steep hill. The maddening nature of the punishment was reserved for King Sisyphus due to his belief that his cleverness surpassed that of Zeus himself. Zeus accordingly displayed his own cleverness by enchanting the boulder into rolling away from King Sisyphus before he reached the top, which ended up consigning Sisyphus to an eternity of useless and worthless efforts and unending frustration. 
Looking at the dysfunctional growth pattern of Nigeria, where as one administration attempts to move the economy forward, then another administration comes in to destroy what its predecessor has built, it is easy to draw some valuable analogy. In Nigeria you will vividly see all the attributes of Sisyphus- hypocrisy, insincerity, morbid wickedness to its citizens, iron-fisted rule and craftiness etc. Regrettably, most Nigerian economists are weighed down by modernization theories that seem to dwell on orthodox growth models and on generalization of 'global economic down-turn' "that things will get better soon". But a good observer will notice that Nigeria's economy has been running a never-ending cyclical peak /trough pendulum for years, and this portrays the economy as suffering from the debacle of the Sisyphus Odyssey.

\section{NIGERIA AND 'DUTCH DISEASE PHENOMENON'}

The term "Dutch Disease" was used to describe the experience of Netherlands after she discovered a massive natural gas field in Groningen in 1959. Incidentally and regrettably too, oil was discovered in large quantity in Nigeria at Oluobiri at the same period of time in history. The flow of oil and gas out of Dutch and the huge revenue that came out of it, made Netherlands to focus primarily on the new gas export. As a result, the Dutch currency grew at a quick rate which harmed the country's ability to export other products. In other words, it eventually led to a crowding out of other traditional export sectors in Netherlands; in case of Nigeria, it crowded out cocoa, Palm oil, and other agricultural produce and even the little industrial manufacturing, leading to a decline in their competitiveness. Many countries that are rich in minerals has fallen prey to this phenomenon - Angola, Nigeria, Sudan, Congo, Gabon, Venezuela, Iraq, Iran, Kuwait, Zambia, and Chad etc. Notwithstanding, some countries (such as Botswana and Norway) have managed to use their natural endowments in ways that have benefited their countries (O'Neil and Patrick (2004).

There may not be a definite pattern to 'Dutch disease' syndrome but a careful observer said it follows this process. Firstly, a nation discovers ample natural resource (oil, gas, gold, platinum etc). Secondly, in a centrifugal nature eeconomic activities begin to flow towards this high income industry. Thirdly, skilled workers from other sectors are attracted to it. Fourthly, other sectors like Agriculture and manufacturing begins to suffer under high cost of doing business. Fifthly, other sectors also begin to lose competitiveness and their export will decline. Sixth, there will be an increase in imports and rent seeking that will lead to crowding out, high exchange rate and inflation.

Various studies such as Sachs and Warner (2001), Weinthal and Luoug( 2006), show amazingly that Countries with great natural resources tend to grow slower than countries that have fewer resources. Based on their survey, GDP per capita in mineralrich countries increased only by $1.7 \%$ while that of mineral-poor countries increased by 2.5-3.5\% between 1960 to 1990; Gylfason (2001) also observed that from 1965 to 1998 gross national product per capita in Organization of Petroleum Exporting Countries (OPEC) decreased on average by 1.3 percent when per capita growth is an average of $2.2 \%$ in the rest of the developing world. That Nigeria, despite having vast oil riches has the same or perhaps less gross national product than it had forty years ago is a victim of this phenomenon. Countries rich in minerals like Iran, Venezuela, grew at 1 per cent per year from 1965-1998 and Iraq and Kuwait grew at 3 per cent. What this portrays is there is a negative effect of oil industry dominance of any economy. 
In figure 1 below, we have the pictorial data of oil revenue and non-oil revenue as drawn from CBN bulletin 2015. Whereas within the period 1966-1970 non-oil revenue accounted for nearly $80 \%$ of total revenue, the oil revenue was a paltry $19 \%$. Again, within the period 1970-1980 the oil revenue contribution has risen and overtaken the non-oil sector $-61 \%$ for oil and 39\% for non-oil. Between 2001-2005 oil revenue was almost $80 \%$ while non-oil was about $20 \%$. By 2015 the oil revenue began to drop, perhaps due to the oil glut and the international fall of oil prices. Figure 2, show vividly that from 1980 the percentage of Oil revenue to GDP was continuously increasing while the non-oil revenue (Agriculture) trailed behind. This is a simple illustration of crowding out effect. That is, the components of oil revenue are now far greater than agriculture, which was the main stay of the economy at Independence in 1960. The implication if any is that oil industry is capital intensive and creates minimal impact on employment. In other words, its income does not spread.

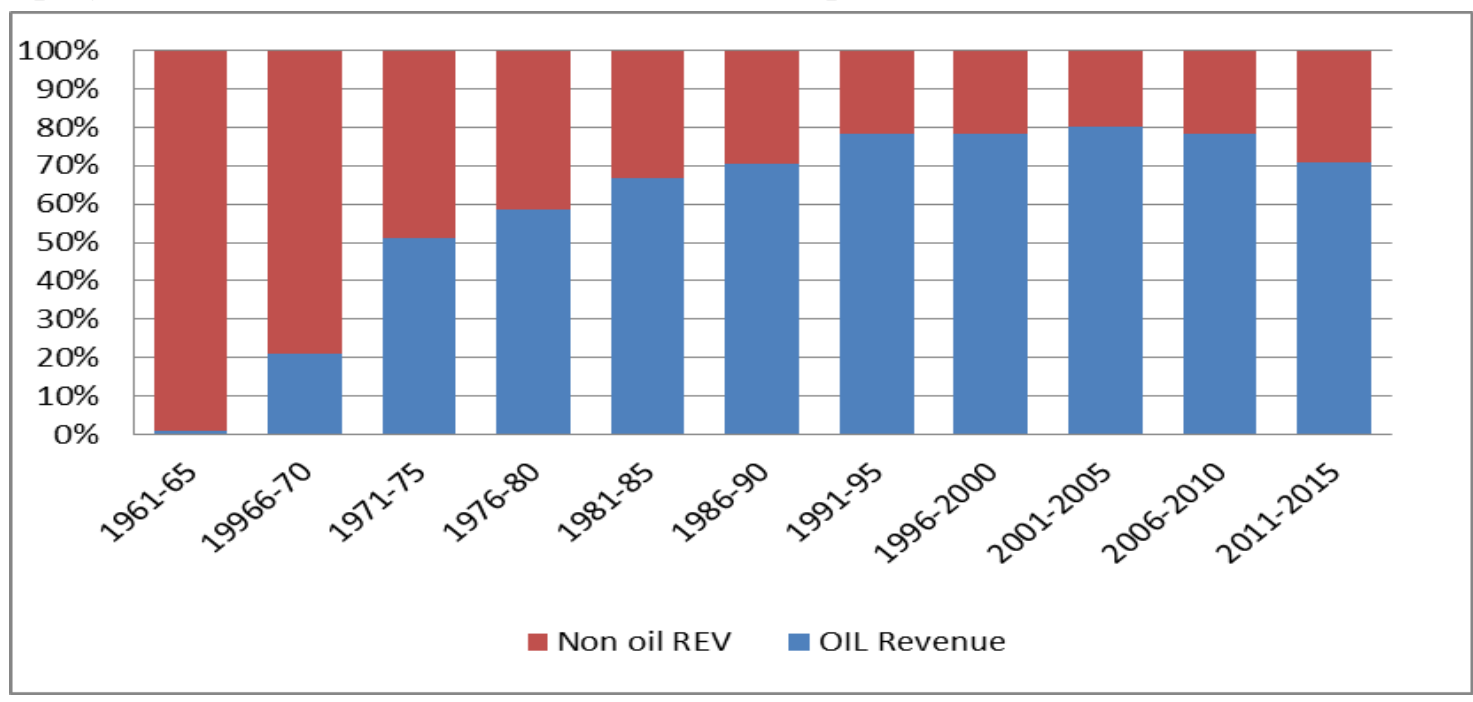

Figure 1. Oil and non-oil revenue as a percentage of GDP

Source: CBN 2015 Bulletin

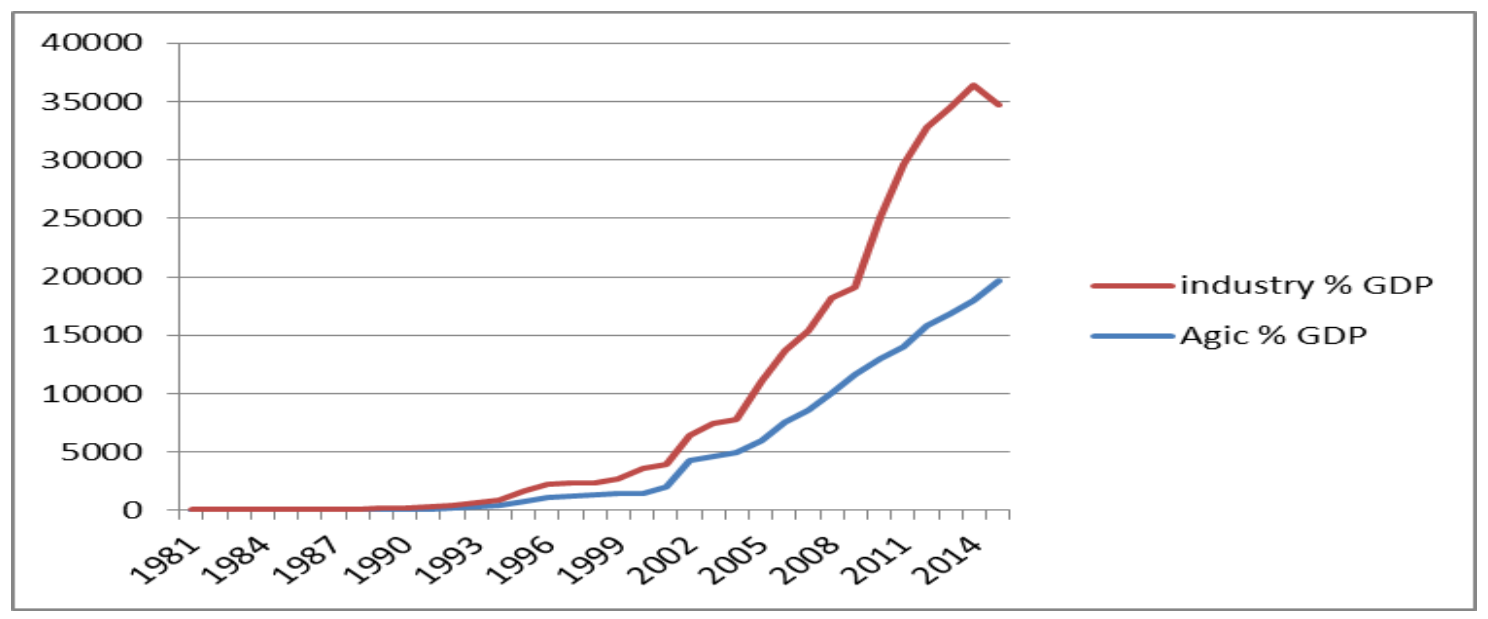

Figure 2. Oil and non-oil revenue as a percentage of GDP

Source: CBN 2015 Bulletin 


\section{NIGERIA'S ECONOMY AND 'RESOURCE CURSE' SYNDROME.}

Resource curse theories began to emerge in the late 1980s. Though often people use it interchangeably with Dutch disease, but they are not the same, though the former may lead to the later. The term was used by Auty Richard (1995), to explain how countries rich in natural resources - oil, gas, diamond, and other minerals misuse their wealth and remain underdeveloped. Jeffery Sachs and Andrew Warner (2001) show the link between natural resources abundance and poor economic growth. They argued that between 1965 and 1998, the oil producing countries (OPEC) gross national product per capita growth decreased on average by $1.3 \%$ against $2.2 \%$ growth per capita in other non-oil producing developing world. There is increasing evidence that because the primary sector remains important in low income countries, the scale of the natural resource rents and the socio-economic linkages that they generate affect the aims of the government and the development trajectory of the economy in important ways (Sachs and Warner 1995a and Auty 2001). Resource rich countries have a tendency to depend on it to run the state at the detriment of other sources of income. Evidence abound that per capita income growth in developing countries has been inversely related to the share of natural resource rents.

Thus, their economic growth pattern is not rooted in production, but rather on fossil product. Resource curse has many negative effects. Nigeria has no doubt benefited from the extravagance and profligacy of resource curse hypothesis. Evidence abounds of the luxury and overindulgence of the elites of Nigeria, especially among the politicians. This luxury living is borne out of excess income and largess and the pervasive corruption found among politicians. The danger of resource curse is the creation of a decadent, dependent and largely consumption patterned, unproductive bourgeoisie. Resource curse increases inequality which even by bourgeoisie standards is dismal to growth. The unproductive nature of the ruling class has become a distortion in itself as people and energies are dissipated at non-essentials, as mobilization of the people for hard work is considered trivial. Regrettably, resource curse has remained with Nigeria since 1970 when Nigeria began to rely in the flow of abundant petrodollar. The situation was so bad that in the middle of 1970s, President Gowan said the only problem of Nigeria was how to spend its money. Resource curse has therefore deepened and reinforced the struggle to develop, and every effort to do so becomes futile. Those who have opportunity to advice the country has over the years wrongly fixated on the rise or fall of GDP and foreign investment flows as attention is now centered on extraction industry. The inability of economists to factor-in institutional factors in discussion of economic growth in Nigeria is to say the least regrettable. Thus, we consider this as acting out the institutional factor syndrome of the Sisyphus odyssey .

\section{NIGERIA'S ETHNIC DIVIDE AS AN OBSTACLE TO GROWTH.}

Again, as a way of introduction, we can say that amalgamation and emergence of modern Nigeria in 1914, was an act of British colonial convenience. It occurred mainly because British colonizers desired a colonial territory stretching from the arid Sahel to the Atlantic Coast, or else the two regions are almost diametrically different or perhaps opposed to each other in virtually every conceivable human adventure. The Northern geopolitical blocs, is largely Muslim, and generally look to the Middle East and the wider Muslim world for solidarity and sociopolitical expression; while the South, an 
ethnically diverse geopolitical region, is largely Christian, predominantly influenced by Western culture and education and traditional African values(Ochonu, 2014). Again, each of the two regions contains ethnic and religious minorities who harbor grievances against dominant ethnic and religious majorities and see them as oppressors. These differences have been a source of political acrimony and mutual suspicions between the two regions since colonial times and have affected growth.

Soyinka (1997), have this to say 'By virtue of its complex web of politically salient identities and history of chronic and seemingly intractable conflicts and instability, Nigeria can be rightly described as one of the most deeply divided states in Africa'. From its inception as a colonial state, Nigeria has faced a perennial crisis of territorial or state legitimacy, which has often challenged its efforts at national cohesion, democratization, stability and economic transformation. It is amazing that most economists in Nigeria do not seem to take this divide as a contending variable in the analysis of the Nigerian economy. The question we want to address is what has ethnic rivalry got to do with economic growth? The answer is Many. When there are profound ethnic divisions in the polity who are the gainers and who are the losers?

1. The first victim is the government itself. Everybody will treat the country like an orphan. Virtually nobody believes in the existence of Nigeria except when you are in power or at its corridor. So deep were these religious and ethnic antagonisms that one Northern Nigerian Muslim nationalist leader declared Nigeria 'the mistake of 1914' while a prominent Southern Nigerian Christian nationalist figure called Nigeria 'a mere geographic expression' (Ochuno, 2014).

2. Mismanagement of national resources (often called common wealth) and misrule by multi-ethnic and multi-religious coalitions of successive rulers since independence have impoverished and denied opportunities to the majority of Nigerians.

3. Through socialization and education, these historical legacies of mistrust and hatred has been genetically transmitted from one generation to another which has become a vivid part of current reality of Nigeria's dysfunctional state.

4. It ends up creating a 'victim mentality' among the people (Richardson and Sen1996). Being a victim in the past, real or imagined, ethnic leaders seek control of state power not to promote industry, not to promote investment, not to promote economic growth or development but to ensure their ethnic group is never victimized again, to right past wrongs and to avenge past oppression. Thus, we hear some leaders come to power for 'ethnic cleansing'.

5. It culminates and encourages political mobilization along ethnic lines. As ethnic differences begin to polarize a society, the formation of militant groups becomes more probable. Examples of such groups include IPOB, MASSOB, AFENERE, NIGER DELTA LIBRATION FORCE, BOKO HARAM, AVENGERS etc. When militant groups become strong, the task of managing the economy - let alone resolving - ethnic differences is greatly complicated.

6. Ordinarily, the conflict borne out of the dis-affections has greatly vitiated, disarticulated, deformed, destroyed and distorted Nigeria's economic growth. Government now build synergy to fight battles and not for growth. Human and materials resources are wasted to fight insurgencies. It will be parochial to ignore the 
dismal effect of ethnicity to economic growth. And Nigeria has suffered this scenario since her independence because that was what led to the first civil war in 1967.

7. Running a non-inclusive government has also been at the center of corruption. This is bad because it is a good environment that will encourage investment and meaningful development, and the circle is bound to continue like the Sisyphus odyssey.

Therefore, it will be full heady and myopic to study the determinants of growth in Nigeria without recourse to the historical underpinning. This short coming to our mind immensely contributed to the nature and character of Nigeria's growth - higgledypiggledy.

\section{RELIGION AND ECONOMIC GROWTH IN NIGERIA: A SYNTHESIS.}

Religion is a prominent aspect of culture that can be a substantial factor in one's quality of life. However, it is often overlooked as a potential determinant of economic growth. And failure to recognize it has created gaps economists are yet to fill. For example, of the six characteristics of modern economic growth that Kuznet, (1973) recognized, secularization was cited as a means of changing ideology in society over time and thus as an indirect cause of economic growth(Korman2015). The result is the restriction of the role of religion in modern economic growth theorizing.

Nigeria's national politics has been characterized by Christian anxieties about perceived Muslim's domination of the national political space, and possibly Islamize national institutions and impose Islamic Sharia law on non-Muslims. And this dates back to colonial times. Muslims on their part have shown dislike for Western ideologies (Boko Haram) and have sporadically sought refuge in obscure religious reforms. Yes, religious reforms that rather impoverish the people. The Emir of Kano is quoted recently to have said that the states that first introduced sharia laws are the poorest states in Nigeria today, and he is right as Zamfara is the poorest state in Nigeria. As a result, religious rhetoric accusing members of other religious communities are making proposals to the government for religious reform as a solution to society's ills. And the idea is beginning to gain currency among the elites and a section of the masses.

It will be recalled that the adoption of the Sharia criminal legal system by some of Northern Nigerian Muslim-majority states between 2000 and 2002 was the climax of this new politicization of religion. Once Sharia was introduced, it only added and reinforced the fear, the feud, the clashes, and the conflict between Christian and Muslim communities. The conflict has led to unprecedented damages of life and property and displacement of millions of people from their homes. Almost on a weekly basis hundreds of souls are lost to communal conflicts arisen from religious intolerance. In this charged environment where religion functions as the primary idiom of political identity, conflicts over resources, cattle, land, and political offices have often taken on a religious coloration, with Muslims pitted against Christians (Ochuno, 2014).The data below will open our eyes to the devastating and damaging effect of religious rascality.

With about 2,152,000 people, Nigeria is reported to have the largest population of persons displaced by conflict in Africa (IDMC, 2016). The internal Displaced Monitoring Center (IDMC) and the Norwegian Refugee Council (NRC) stated that the number of internally displaced persons in Nigeria is approximately a third of the IDPs in Africa and 10 percent of IDPs in the world. The IDPs in Nigeria is bigger than population of some countries in Africa: For example Nigeria's IDP alone is bigger than 
Gabon, Gambia, Guinea, Botswana, Swaziland and Lesotho etc. This figure is based on an assessment conducted from November to December 2015 by the International Organization for Migration's (IOM) Displacement Tracking Matrix (DTM) team in 207 Local Government Areas (LGA) covering 13 States of Northern Nigeria: Abuja (13,481IDPs);Adamawa (136,010); Bauchi (70,078); Benue (85,393); Borno $(1,434,149)$; Gombe (25,332); Kaduna (36,976); Kano (9,331); Nasarawa $(37,553)$; Plateau (77,317); Taraba (50,227); Yobe (131,203); and Zamfara (44,929) (IDMC, 2016).

Figure 3 below shows the composition and classification of the total figure of internal displaced persons (IDPs), the assessment indicates that 12.6 per cent were displaced due to communal clashes, 2.4 per cent by natural disasters and 85 per cent as a result of insurgency attacks by Islamic extremist. This number of healthy people that are quarantined because of Boko Haram would have made their small input to the national income accounting. In other words they have been denied access to good life and also disenfranchised from contributing to the economy's growth.

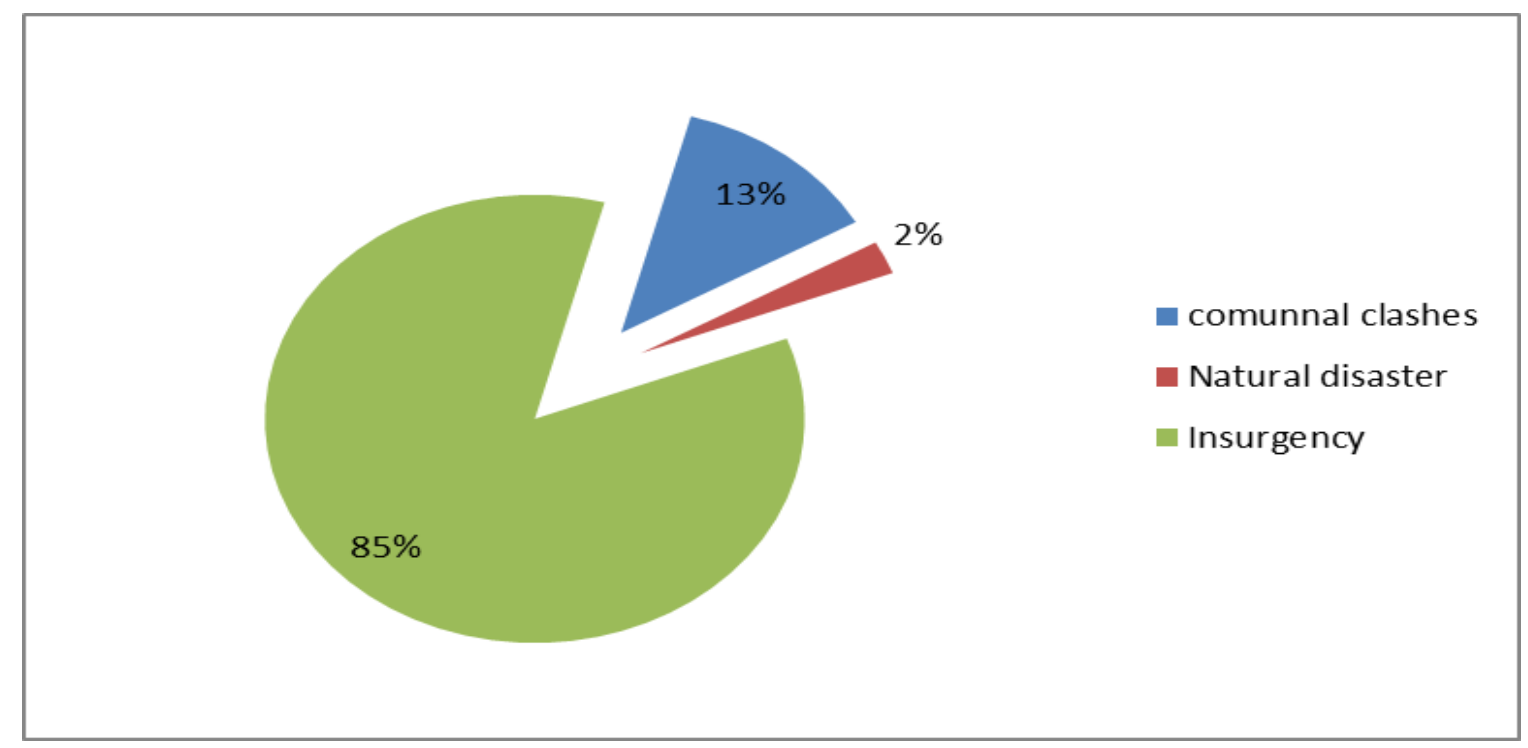

Figure 3: The composition of Nigeria’s IDPs 'inmates'.

The following are some of the damaging effect of projecting religion over economic values.

1. Official graft and war against corruption will never be won because politicians and their surrogates hide under the cleavages of religion frustrate the economy..

2. Organized religion has influenced laws and regulations that affect economic incentives; especially in taxation, establishment of some industries, in banking etc. Nigeria does not have a stable education policy today because of differences in the educational attainment of the regions and religious groups. One group may be forward looking while the other will be 'slow going'.

3. The religious bigotry has limited cross breed of ideas and idea 'and ideologies in the country. You will find excess lecturers in Universities South of the country and almost non-qualified lecturers on the other side of the divide. 
4. The marking, the grading, and the promotion system in the tertiary institutions follows the same divide, they are not the same and the gaps are very wide.

5. The Boko Haram tragedy that has caused the loss of lives and displaced innumerable number of people is propelled by religion. And all these are harmful to economic growth.

\section{TAMING THE SONS OF SISYPHUS: BEYOND RHETORIC'S.}

Often we see over bloated recommendation that the way out of the Nigeria economic quagmire is diversification of economy. Over bloated because the call is not founded on realistic assumptions. Just as the dictum that agriculture (in the $21^{\text {st }}$ century) is the only way out for Nigeria to grow. But because many Nigerian economists are carried away by econometric simulations, they give little or no attention to historical antecedents. They easily forget that the very essence of structural adjustment programme in 1986 was to diversify the economy. They are also ignorant or perhaps they have chosen to play the 'ostrich' that since 1986 till today, all regimes that have been in place in Nigeria, whether Military or civilian has risen to power on this platform and yet not one of these regimes has demonstrated readiness to initiate diversification. It is more like "no go area". There are fundamental reasons why diversification cannot work now in Nigeria. For example,

Only petroleum ( and Nigeria has enough of it) is consistently correlated with less democracy and more corruption, but both petroleum and other mineral resources have been statistically associated with civil wars (Collier et al. 2009, Besley \& Persson 2011, Sorens 2011). Oil is more likely to spark conflict when it is found in regions that are poor relative to the national average (Østby et al. 2009) and populated by marginalized ethnic groups (Basedau \& Richter 2014, Hunziker \& Cederman 2012); when it is located in a region with a highly concentrated ethnic group (Morelli \& Rohner 2014); and when ethnic minority entrepreneurs use it to promote collective resistance to the central government (Aspinall 2007). If you look at the case of Nigeria it is easy to discover all these indices vis-à-vis our Niger Delta region. The mismanagement of the petrodollar has created a veritable ground for disharmony in the polity. People have not been mobilized for production but consumption.

What should be clear enough is measurement of Nigeria's economic growth based on GDP, interest rate, FDI, capital formation and other macro-economic variables as determinants of growth may certainly amount to rhetorics. Realistically when we assess the causes and costs of prolonged ethnic conflict in Nigeria, one may begin to convince development planners that programs which significantly increase the risks of violence and ethnic conflict are not economically justifiable. We want to state categorically, that it is not economically justifiable to place one ethnic group alone to manage all economic ventures of a country of about 250 ethnic groups and a population of 180 million people. Nigeria is absolutely poor today not because it doesn't have the human or material resources, but there is no cohesion and mobilization of the right people for development. Our assessment should alert present and aspiring national leaders to a harsh reality: the short term benefits from ethnically divisive political strategies do not justify the long term social economic and political costs.

Therefore, a political economy approach, and dialectical process may be required to tame the sons of Sisyphus. As a matter of fact what Nigeria needs is a genuine, 
sincere dialogue between and among the component ethnic groups on how to establish harmonious co-existence which in turn will make the governance, and investment environment healthy for business. Patriotism cannot be won in isolation of trust and mutual relationship and belief in the polity.

\section{CONCLUSION.}

Why has Nigeria's economic problem become highly intractable? The answer to this question is no longer far-fetched. What means nothing to many countries of the world mean something in Nigeria? Take for example when the CBN approved the opening of an interest free Islamic Bank, the Christians opposed it with the fear that they (Sanusi the CBN Governor then) wants to Islamize the country. The major opposing tribes are always involved as well as their religion. The issue becomes worse when a non-liberal Moslem or Christian is in the helm of affairs. This has played out over the years by given Nigeria an epileptic and dysfunctional growth pattern 56 years after independence and there is no end in sight as to the best way to fix it. The best economist from IMT or Harvard University will fail to move Nigeria forward if he does not take recourse to Nigeria's history. We say the ethnic divide and the religious bigotry has been entrenched in the psych of the people to the point that people are not mobilized for economic development but for war. Mutual suspicion has determined the way business of the economy is run; therefore meaningful development cannot take place here. So apart from the obvious Dutch disease syndrome, these other diseases(sons of Sisyphus) are perhaps more potent as a tool to destroy and destabilize the economy. The need to address them is urgent and it is now.

\section{REFERENCES}

Anochiwa ,L.I and Maduka, A. (2014). Nigeria the Largest Economy in Africa: A Paradox of Economic Growth Hypothesis. EPRA International Journal of Economic Review, Vol 2. Issue 11

Aspinall E. 2007. The construction of grievance: natural resources and identity in a separatist conflict. J. Confl.Resolut.51(6):950-72

Auty RM. 1993.Sustaining Development in the Mineral Economies: The Resource Curse Thesis. London: Routledge

Auty, RM (1995), 'Industrial policy, sectoral targeting and post-war economic growth in Brazil: The resource curse thesis', Economic Geography 71: 257-272.

Auty, Richard (2001) (ed.), Resource Abundance and Economic Development, Oxford:Oxford University Press.

Barro, R.J and X. Sala-i-Martin (1995).Economic Growth. New York, McGrawHill

Barro RJ. (1999). Determinants of democracy.J. Polit. Econ. 107(6):S158-83

Basedau M, Lay J. (2009). Resource curse or rentier peace? The ambiguous effects of oil wealth and oil dependence on violent conflict. J. Peace Res. 46(6):757-76

BasedauM, Richter T. 2014. Why do some oil exporters experience civil war but others do not? A Qualitative comparative analysis of net oil-exporting countries.Eur. Polit. Sci. Rev. 6(4):549-74

Besley T, Persson T. (2011). The logic of political violence.Q. J. Econ. 126:1411-45

Chaudhry KA. (1997). The Price of Wealth: Economies and Institutions in the Middle East. Ithaca, NY: Cornell University. Press 
Chenery, Hollis and Allen Strout (1966).Foreign Assistant and Economic Development.American Economic Review, vol 50 No 4, part 1

Collier P, Hoeffler A, Rohner D. 2009. Beyond greed and grievance: feasibility and civil war. Oxf.Econ. Pap.61:1-27

Collier P. (2010). The Plundered Planet. New York: Oxford Univ. Press

Domar, E.D (1946). Capital Expansion, rate of growth and employment. Econometrica 14: $137-147$

Harrod, R.F (1939). An essay in dynamic theory.Econ journal 49:14-33.

Hunziker P, Cederman LE. (2012). No extraction without representation: petroleum production and ethnonationalist conflict. Unpublished manuscript

IDMC,( 2016). IDMC's 2016 yearly report on internal displacement, published in May Address: 3 Rue de Varembè, 1202 Geneva, Switzerland Phone N0: +41 22552 3600

Jevons W. Stanley (1879).The Theory of Political Science. 2nd ed. P. xiv

Korman, Sophia M. (2015)."Examining the Effect of Religion on Economic Growth: A Partial Replication and Extension" (2015).HonorsTheses.Paper89. http://digitalcommons.csbsju.edu/honors theses/89

Kuznets, S. (1973). Modern economic growth: Findings and reflections. The American Economic Review, 63(3), 247-258. Retrieved fromhttp://www.jstor.org/stable/1914358?seq

Morelli M, Rohner D. (2014). Resource concentration and civil wars.NBERWork.Pap. 20129

Ochonu Moses (2014). The roots of Nigeria's religious and ethnic conflict Global post https://www.pri.org/stories/2014-03-10/roots-nigerias-religious-andethnicconflict

O'Neil, Patrick (2004). Essentials of Comparative Politics. New York, London: Norton. p. 147.

Ordeshook Peter C. (1990). The Emerging Discipline of Political Economy".In perspective on Positive Political Economy, Cambridge pp 9-30.

Østby G, Norda ${ }^{\circ}$ R, Rød JK. (2009). Regional inequalities and civil conflict in subSaharan Africa.Int. Stud. Q.53(2):301-24

Richardson John and ShinjineeSen (1996). Ethnic conflict and Economic Development: A policy oriented analysis. School of International Services. American University

Romer, Paul (1993).“Idea Gaps and Object Gaps in Economic Development”.Journal of Monetary Economics, 32: 543-73

Ross ML. (2001a). Does oil hinder democracy? World Polit. 53(3):325-61

Sachs J,Warner A. 1995. Natural resource abundance and economic growth. Dev. Disc. Pap. 517a, Harvard Inst.Int. Dev., Cambridge, MA

Sachs J.D. and A.M. Warner (2001).The Curse of National Resources. European Economic Review, 45 s, 827-838.

Solow, R.M(1956).'A contribution to the Theory of Economic Growth'.Quarterly journal of Economics 70:65-94

Sorens J. (2011). Mineral production, territory, and ethnic rebellion: the role of rebel constituencies. J. PeaceRes. 48(5):571-85 
Soyinka, W.(1997). The Open Sore of a Continent: A Personal Narrative of the Nigerian Crisis. Oxford: Oxford University Press.1997.

Venables, Anthony J. ( 2016). "Using Natural Resources for Development: Why Has It Proven So Difficult?". Journal of Economic Perspectives 30 (1): 161-184. doi:10.1257/jep.30.1.161.

Weinthal, E., and Luong, P., 2006. Combating the Resource Curse: An Alternative Solution to managing Mineral wealth.Perspectives on Politics Journal. Volume 4, pp 35-53. (online). Available at: http:// www.jstor.org/stable/3688625. 